\title{
EFFECT OF GRATEFULNESS TRAINING ON PROMOTING OPTIMISM AMONG WOMEN WITH SOCIAL PROBLEM
}

\author{
Rini Lestari \\ Faculty of Psychology, Universitas Muhammadiyah Surakarta
}

\begin{abstract}
Background: Many studies have been carried out about the effectiveness of optimism as a psychological phenomenon. A significant positive relation emerges between optimism and coping strategies focused on social support and emphasis on positive aspects of stressful situations. The purpose of this study was to examine the effect of gratefulness training on promoting optimism among women with social problem.

Subjects and Method: This was an experiment study. A sample of 29 women with social problem divided into two groups. Gratefulness training was conducted in 5 sessions. The dependent variable was optimism. The independent variable was gratefulness training. Data on optimism were measured by optimism scale. The data were analyzed by Mann Whitney. Results: Grateful training increased optimism among women with social problem.

Conclusion: Grateful training can be used as a psychology intervention model to increase optimism among women with social problem.
\end{abstract}

Keywords: gratefulness training, optimism, women with social problem

\section{Correspondence:}

Rini Lestari. Faculty of Psychology, Universitas Muhammadiyah Surakarta. Jl. A. Yani, Mendungan, Pabelan, Kartasura, Sukoharjo 57162, Central Java. Email: rini.lestari@ums.ac.id

The 5th International Conference on Public Health Best Western Premier Hotel, Solo, Indonesia, February 13-14, 2019 | 234 https://doi.org/10.26911/theicph.2019.02.44 